CLINICAL STUDY

\title{
Relationship between cytokeratin staining patterns and clinico-pathological features in somatotropinomae
}

\author{
Yuriz Bakhtiar, Hirofumi Hirano, Kazunori Arita, Shunji Yunoue, Shingo Fujio, Atsushi Tominaga ${ }^{1}$, \\ Tetsuhiko Sakoguchi $^{1}$, Kazuhiko Sugiyama ${ }^{1}$, Kaoru Kurisu ${ }^{1}$, Junko Yasufuku-Takano ${ }^{2}$ and Koji Takano ${ }^{2}$ \\ Department of Neurosurgery, Graduate School of Medical and Dental Sciences, Kagoshima University, 8-35-1, Sakuragaoka, Kagoshima 890-8520, \\ Japan, ${ }^{1}$ Department of Neurosurgery, Graduate School of Biomedical Science, Hiroshima University, Hiroshima 734-8551, Japan and ${ }^{2}$ Department of \\ Nephrology and Endocrinology, Faculty of Medicine, University of Tokyo, Tokyo 113-8655, Japan \\ (Correspondence should be addressed to K Arita; Email: karita@m2.kufm.kagoshima-u.ac.jp)
}

\begin{abstract}
Objective: Somatotropinomae are classified as densely and sparsely granulated adenomae, which typically exhibit a perinuclear pattern (PP) and a dot pattern (DP) in cytokeratin (CK) immunostaining respectively. Some exhibit a mixed pattern (MP). We studied the relationship between these somatotropinoma subtypes and their clinico-pathological features.

Methods: The study population consisted of 141 Japanese acromegalic patients. We evaluated their clinical presentation and their response to provocation tests with TRH and LHRH and to suppression (octreotide) test. Tumour tissues were subjected to immunostaining for CAM-5.2, MIB-1, CD34, E-cadherin (CDH1) and p53 (TP53). In 43 cases (30 non-DP and 13 DP), we analysed gsp mutations (constitutively activating mutations of the $\mathrm{G}_{\mathrm{s}} \alpha$ protein that is encoded by GNAS gene).

Results: The 141 adenomae were categorised into three subtypes based on their CK staining patterns; $30(21.3 \%)$ exhibited DP, 83 (58.9\%) exhibited PP, and 28 (19.9\%) exhibited MP. Compared with the other subtypes, DP adenomae were significantly larger, and their E-cadherin expression and response to TRH, LHRH and octreotide challenge were lower. The postoperative cure rate tended to be lower in DP adenomae. gsp mutations were detected in 25 of 43 cases examined (58.1\%); 20 of the 30 non-DP $(66.7 \%)$ and 5 of the 13 DP tumours $(38.5 \%)$ were affected by the mutation.

Conclusion: DP somatotropinomae exhibit characteristic features. Compared with the non-DP subtypes, DP adenomae manifested a larger tumour size, a lower incidence of abnormal responses to TRH and LHRH challenge, a poor response to octreotide test and a lower expression of E-cadherin. gsp mutation was not exclusive for non-DP somatotropinomae.
\end{abstract}

European Journal of Endocrinology 163 531-539

\section{Introduction}

Human pituitary adenomae are benign neoplasms that account for about $15-20 \%$ of all intracranial neoplasms (1-3). Based on their electron microscopic features, somatotropinomae or GH-producing adenomae (GHomae) that produce acromegaly and gigantism are classified into two subtypes $(1,4,5)$, i.e. densely and sparsely granulated (DG and SG) tumours. The DG subtype manifests abundant closely packed secretory granules of large to medium size. Most tumour cells are polyhedral or elongated with spherical euchromatic nuclei containing conspicuous nucleoli. In the cytoplasm, well-developed Golgi apparatus harbouring immature developing granules and elongated cristae in the mitochondria are observed $(1,4,5)$. These features are distinct from SG subtype adenoma cells whose cytoplasm contains scarcely distributed small secretory granules and fibrous bodies. The perinuclear pattern (PP) and dot pattern (DP) in cytokeratin (CK) immunostaining observed under light microscopy can be good surrogate for the electron microscopic features of the DG and SG subtype adenomae respectively $(1,6)$. However, there are some adenomae that exhibit a combined feature of PP and DP or the mixed pattern (MP) (7-11).

The fibrous body is an intracytoplasmic globular aggregation of filaments containing CK, which belongs to the intermediate filament protein family $(6,7$, 12-14). Apart from its role in the formation of cell frameworks, CK has other important functions, and disorganised CK distribution may result in the disruption of cellular functions (14). The CK immunostaining pattern is related to epithelial malignancies and reflects ongoing cell activity (15). However, the molecular background and pathophysiology of the two GHoma phenotypes remain to be elucidated.

The $g s p$ mutation is a somatic activating mutation of the $\alpha$ subunit of the heterotrimeric $\mathrm{G}_{\mathrm{s}}$ protein encoded by the GNAS gene $(16,17)$. It is thought to be an early 
event in tumourigenesis and is detected in $\sim 40-50 \%$ of sporadic GHomae (18-22). There have been few studies on the impact of $g s p$ mutations on the GHoma subtypes $(19,23)$; this mutation has been documented only in DG GHomae $(19,23)$.

In this study, we retrospectively evaluated clinicopathological features of GHomae with their respective CK pattern in acromegalic patients. The relationships between the CK pattern and gsp mutation were investigated as well.

\section{Materials and methods}

\section{Subjects}

The study population consisted of 141 Japanese patients with GHoma who underwent transsphenoidal adenomectomy in our hospitals. Before surgery, none had been treated with dopamine receptor subtype-2 $\left(\mathrm{D}_{2}\right)$ agonists, somatostatin analogues (except for the single challenge test) or irradiation.

\section{Acquisition of clinical data}

Clinical data and the patient's age and sex, symptoms, hormonal profiles and tumour morphologies were obtained from clinical records and preoperative magnetic resonance imaging (MRI) scans.

\section{Hormonal evaluation}

Plasma GH and insulin-like growth factor 1 (IGF1) levels were measured for routine preoperative endocrine evaluation. The $\mathrm{GH}$ responses to TRH $(500 \mu$ g, i.v. $)$, LHRH (100 $\mu \mathrm{g}$, i.v.) and octreotide $(50 \mu \mathrm{g}$, s.c. $)$, expressed as the ratio (\%) of the maximum or minimum $\mathrm{GH}$ level to the basal $\mathrm{GH}$ level, were evaluated on different days. An abnormal response to TRH or LHRH was defined as an increase in the GH level to $200 \%$ or more of the baseline value. A good response to the octreotide test was defined as a $\geq 90 \%$ or greater decrease in the $\mathrm{GH}$ level from the baseline during testing. Postoperative cure was defined according to the Cortina consensus criteria (24), i.e. as a GH nadir during postoperative oral glucose tolerance test (OGTT, $<1 \mathrm{ng} / \mathrm{ml}$ ) and normalisation of serum IGF1 based on the standard value for the Japanese population. Of the 141 patients, 127 underwent postoperative OGTT.

\section{Imaging studies}

The maximum tumour diameter was measured on preoperative MRI scans. The tumour volume $\left(\mathrm{cm}^{3}\right)$ was estimated using the formula: $0.5 \times$ width $\times$ length $\times$ height (25). Cavernous sinus invasion by the tumour was judged to be present when the preoperative MRI scan showed an internal carotid artery surrounded by the tumour (Knosp's grade IV lateral growth) (26) or when there was intraoperative microscopic and/or endoscopic evidence of disruption of the medial wall of the cavernous sinus and lateral extension of the tumour through the window.

Patients with a documented history of pituitary apoplexy were excluded from this study. GH-producing indices were calculated based on the ratio of the preoperative $\mathrm{GH}$ level $(\mathrm{ng} / \mathrm{ml})$ per $\mathrm{cm}^{3}$ of the tumour volume $\left(\mathrm{ng} / \mathrm{ml}\right.$ per $\left.\mathrm{cm}^{3}\right)(8)$.

\section{Histological studies}

Surgically isolated adenomae tissues were fixed in 10\% formaldehyde and embedded in paraffin before cutting into thin slices ( $3 \mu \mathrm{m}$ thick) for light microscopy and light microscopic immunohistochemistry. The $3 \mu \mathrm{m}$ thick sections were stained with haematoxylin and eosin (H\&E) reagent (Figs $1 \mathrm{~A}$ and 2A). Although we had intended to exclude acidophilic adenomae with hyperprolactinaemia characterised by clear cytoplasmic vacuoles and dot-like CK positivity to eliminate possible contamination with acidophilic stem cell adenomae (1), we could not identify this rare type of adenomae. Immunohistochemistry was performed with the avidin-biotin-peroxidase complex method, where diaminobenzidine was used for antigen visualisation. The specific antibodies are listed in Table 1. Microwave antigen retrieval was performed in citrate buffer $(\mathrm{pH}$ 6.0). Positivity for CAM-5.2, anti-CK reagent, was classified into three patterns: i) DP (dot-like CK positivity limited to fibrous body), ii) PP (diffuse CK-positive response in cytoplasm mainly with perinuclear preference) and iii) MP (adenomae with various mixed ratios of
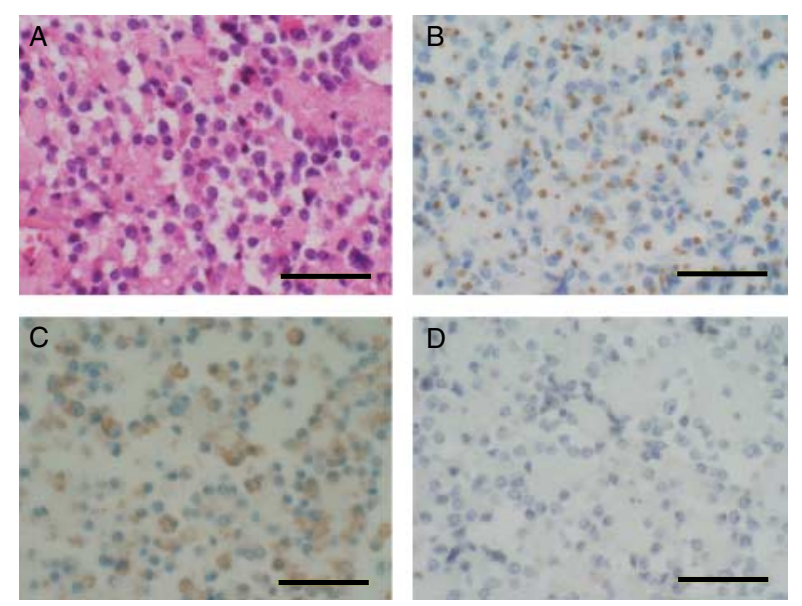

Figure 1 Histological examination of a somatotropinoma (GHoma) with a dot pattern (DP) in a 47-year-old woman. Bar: $50 \mu \mathrm{m}$. (A) Haematoxylin and eosin (H\&E) staining revealed that the neoplastic cells were acidophilic. (B) CAM-5.2 immunostaining was used to categorise this tumour as a DP subtype based on the intracytoplasmic globular aggregation of intermediate filaments containing cytokeratin. (C) The tumour showed diffuse immunoreactivity with $\mathrm{GH}$. (D) The tumour did not display membranous expression of E-cadherin. 

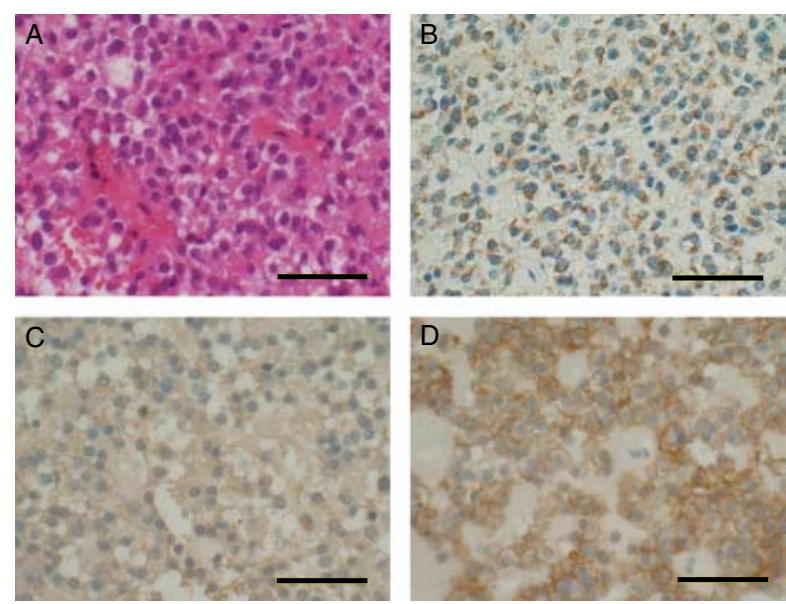

Figure 2 Histological examination of a GHoma with a perinuclear staining pattern (PP) in a 57-year-old man. Bar: $50 \mu \mathrm{m}$. (A) H\&E staining revealed that the tumour was acidophilic. (B) CAM-5.2 immunostaining was used to categorise this tumour as a PP subtype based on the perinuclear distribution of cytokeratin.

(C) The tumour was diffusely immunoreactive with GH.

(D) Membranous immunoreactivity of E-cadherin was diffusely observed in this tumour.

DP and PP). Cells immunoreactive to $\mathrm{GH}$, prolactin (PRL), TSH and p53 were counted and expressed as a percentage of stained cells of more than 500 adenomae cells at $400 \times$ magnification. Cells immunoreactive to E-cadherin (CDH1) were also quantitatively assessed and expressed as a percentage of cells that stained positive on the plasma membrane. The microvascular density (MVD) was assessed by counting the number of lumen with CD34 positive staining at $400 \times$ magnification. MIB-1 index reflecting proliferating cell ratio was calculated from more than 500 cells.

\section{gsp gene mutation study}

For $g s p$ mutation analysis, 43 frozen GHoma specimens were available. Their number was restricted because in some cases the amount of tumour tissue was too small

Table 1 List of antibodies used for immunohistochemical detection.

\begin{tabular}{|c|c|c|c|}
\hline $\begin{array}{l}\text { Antibodies } \\
\text { agents }\end{array}$ & Sources & $\begin{array}{l}\text { Nature of } \\
\text { antibodies }\end{array}$ & Dilutions \\
\hline CAM-5.2 & Becton Dickinson $^{a}$ & Monoclonal & $-b$ \\
\hline $\mathrm{GH}$ & $\mathrm{DAKO}^{\mathrm{C}}$ & Polyclonal & $1: 100$ \\
\hline PRL & Immunotech $^{\mathrm{d}}$ & Monoclonal & $1: 100$ \\
\hline$\beta \mathrm{TSH}$ & Immunotech & Monoclonal & $1: 100$ \\
\hline $\mathrm{KI}-67$ & $\mathrm{DAKO}^{\mathrm{C}}$ & Monoclonal & $1: 50$ \\
\hline CD34 & $\mathrm{DAKO}^{\mathrm{c}}$ & Monoclonal & $-b$ \\
\hline E-cadherin & Cell Signalling ${ }^{\mathrm{e}}$ & Monoclonal & $1: 25$ \\
\hline p53 & Beckman Coulter ${ }^{d}$ & Monoclonal & $-{ }^{b}$ \\
\hline
\end{tabular}

${ }^{\mathrm{a}}$ Franklin Lakes, NJ, USA.

${ }^{\text {bNo dilution. }}$

${ }^{\mathrm{C}}$ Glostrup, Denmark.

dMarseille, France.

eDanvers, MA, USA. to be prepared as frozen sample or because protocols for the acquisition of frozen tissues were not uniform. Two authors (K T and J Y-T), blinded to clinical and pathological data, subjected the available frozen tissues to mutation analysis. The mean diameter of the 43 tumours used for mutation analysis and of all 141 tumours was similar $(19.6 \pm 8.1 \mathrm{~mm}$ (s.D.) and $18.7 \pm 9.6 \mathrm{~mm}$ respectively).

The specimens were preserved under $-80{ }^{\circ} \mathrm{C}$ until RNA extraction. Total RNA contents were extracted from the adenomae tissues, and the first-strand cDNA was synthesised from $5 \mu \mathrm{g}$ total RNA by RT-PCR after removing contaminating genomic DNA as reported previously (18). To amplify the specific $\mathrm{G}_{\mathrm{s}} \alpha$-subunit cDNA fragment (249 bp), including codons 201 and 227 of the $G s \alpha$ gene, we designed a sense primer and an antisense primer corresponding to nucleotide sequences 562-585 (5'-GTGTATCAAGCAGGCTGACTATGTG-3') and 793-819 (5'-CAGGCGGTTGTTCTGGTT-3') respectively. Using these primers, the PCR was performed to amplify the aforesaid first-strand cDNA, although the temperature for annealing was changed to $60^{\circ} \mathrm{C}$ for 40 cycles. The PCR product was purified and directly sequenced using ABI PRISM software (Applied Biosystems, Foster City, CA, USA).

\section{Statistical analysis}

The SPSS software program (version 15.0, IBM Co., Chicago, $\mathrm{IL}$, USA) was used for statistical analysis of the results. The data was analysed by the contingency $C$ test followed by Fisher's exact test, the Kruskal-Wallis test and/or the Mann-Whitney $U$ test where appropriate. Differences of $P<0.05$ were considered statistically significant.

\section{Ethical considerations}

This retrospective study was approved by the Kagoshima University Hospital Ethical Committee (reference no: 2008-144).

\section{Results}

As we found that the clinical features of MP and PP adenomae were similar, we present our findings as comparisons between DP and non-DP (i.e. combined MP and PP) GHomae.

\section{Patient profiles}

The gender distribution in the 141 patients, 64 males and 77 females, was comparable; their age ranged from 9 to 75 years $(48.9 \pm 13.5$, mean \pm s.D.; Table 2$)$. The mean preoperative $\mathrm{GH}$ level was $62.1 \pm 183.7 \mathrm{ng} / \mathrm{ml}$. Abnormal responses to TRH and LHRH tests were observed in 75 and $16.7 \%$ of 128 patients respectively; $12(30.8 \%)$ of 39 patients had a good response to the 
Table 2 Demographic and clinical data of subjects.

\begin{tabular}{ll}
\hline Variable & \\
\hline Sex & Male 64, female 77 \\
Age (years) & $48.9 \pm 13.5$ \\
Preoperative GH level $(\mathrm{ng} / \mathrm{ml})$ & $62.1 \pm 183.7$ \\
Tumor diameter $(\mathrm{mm})$ & $18.7 \pm 9.6$ \\
Microadenomae & $21(14.9 \%)$ \\
Macroadenomae & $120(85.1 \%)$ \\
Tumor volume $\left(\mathrm{cm}^{3}\right) \pm$ s.D. & $6.6 \pm 13.1$ \\
GH-producing index $\left(\mathrm{ng} / \mathrm{ml}\right.$ per $\left.\mathrm{cm}^{3}\right)$ & $21.9 \pm 36.1$ \\
TRH test $(n: 128)$ & $96(75 \%)$ \\
Abnormal response & $32(25 \%)$ \\
Normal response & $21(16.7 \%)$ \\
LHRH test $(n: 128)$ & $107(83.3 \%)$ \\
Abnormal response & \\
Normal response & $12(30.8 \%)$ \\
Octreotide test $(n: 39)$ & $27(769.2 \%)$ \\
Good response & \\
Poor response & $72(56.7 \%)$ \\
Surgical outcome $(n: 127)$ & $55(43.3 \%)$ \\
Cured &
\end{tabular}

Abnormal response, increases of the $\mathrm{GH}$ level to $200 \%$ or more; a good response, $\geq 90 \%$ decreases in $\mathrm{GH}$ levels from the preoperative basa $\mathrm{GH}$ level during examination; cured, nadir $\mathrm{GH}$ during glucose tolerance test $<1.0 \mathrm{ng} / \mathrm{ml}$ and normalised IGF1 level (based on standard value for normal Japanese population).

octreotide test. Of the 141 patients, $21(14.9 \%)$ manifested microadenomae, the other $120(85.1 \%)$ harboured macroadenomae. Postoperative cure was obtained in $72(56.7 \%)$ of 127 patients who underwent postoperative OGTT.

\section{CK patterns and clinical features}

Based on the classification criteria described in Materials and methods, of the 141 tumours, 30 (21.3\%) were DP (Fig. $1 \mathrm{~A}$ and B), 83 (58.9\%) were PP (Fig. 2A and B), and 28 (19.9\%) were MP subtype tumours (Table 3). The mean age tended to be lower in patients with DP adenomae than those with non-DP adenomae $(45.0 \pm 16.1$ vs $50.1 \pm 12.6$ years, $P=0.098)$. The mean maximal tumour diameter of DP, PP and MP adenomae was 23.5 $\pm 11.5,17.5 \pm 8.9$ and $16.8 \pm 8.2 \mathrm{~mm}$ respectively; DP GHomae were significantly larger than non-DP tumours $(P=0.006)$. The volume of DP GHomae was also significantly larger than that of non-DP adenomae $(11.7 \pm 18.4$ vs $\left.5.3 \pm 10.9 \mathrm{~cm}^{3}, P=0.006\right)$. GH-producing index tended to be lower in DP adenomae $(17.3 \pm 22.2 \mathrm{ng} / \mathrm{ml}$ per $\left.\mathrm{cm}^{3}\right)$ than in non-DP adenomae $(23.2 \pm 39.1 \mathrm{ng} / \mathrm{ml}$ per $\left.\mathrm{cm}^{3}\right)(P=0.145)$. On the other hand, with respect to tumour invasiveness, there was no significant difference between the tumour types.

Significantly more patients with non-DP tumours than those with DP tumours manifested an abnormal response to TRH (81.2 vs $51.9 \%, P=0.003)$ and $\mathrm{LHRH}$ challenge (19.8 vs $3.7 \%, P=0.034$ ) and a good response to octreotide ( 42.9 vs $0 \%, P=0.008$ ).

Of the 127 patients who underwent postoperative OGTT, $72(56.7 \%)$ obtained postoperative cure. Although the postoperative cure rate was better in patients with non-DP adenomae than those with DP adenomae (60.4 vs $42.3 \%)$, the difference was not statistically significant $(P=0.076)$.

\section{Immunohistochemistry}

Most of the adenoma cells were diffusely immunoreactive with GH (Figs $1 C$ and 2C; Table 4). Between DP and non-DP adenomae, there was no significant difference in the percentage of $\mathrm{GH}$-immunopositive cells, nor in the percentage of cells immunopositive for other anterior pituitary hormones. The MIB-1 index was higher in DP GHomae than in non-DP GHomae $(0.72 \pm 1.6$ vs $0.20 \pm 0.39 \%, \quad P=0.086)$. The expression of MVD was almost the same between the two groups. Although not statistically significant $(P=0.101)$, the expression of p53 was slightly higher in DP GHomae. Lastly, the expression of E-cadherin involving the CK network (27-29) was significantly $(P<0.001)$ lower in DP GHomae than in non-DP GHomae (Figs 1D and 2D).

\section{gsp mutations}

The mutation was detected in 25 of 43 (58.1\%) tumours examined. Incidence of $g s p$ mutation tended to be higher in non-DP $(66.7 \%)$ adenomae than in DP (38.5\%) adenomae $(P=0.083$; Table 5$)$. There were four different mutations; they were Arg to Cys in codon 201 (68\%), Arg to Ser in codon 201 (8\%), Gln to Leu in codon 227 (20\%) and Gln to Arg in codon 227 (4\%).

The clinico-pathological features (including age, sex, basal GH level and MIB-1 index) of the 43 patients whose tumours were subjected to mutation analysis were not significantly different, irrespective of their mutation status. Also, there was no significant difference with respect to immunoreactivity to $\mathrm{GH}$, PRL or TSH (data not shown). On the other hand, the tumour size was significantly smaller $(P=0.006)$ and the GH-producing index was significantly larger $(P=0.007)$ in adenomae with $g s p$ mutations than those without gsp mutations. In addition, while all tumours with the mutation manifested an abnormal response to TRH challenge, this was the case in $50 \%$ of adenomae without $g s p$ mutations $(P<0.001)$. We observed a good response to octreotide in $44.4 \%$ of adenomae with $g s p$ mutations and in $18.2 \%$ of tumours without the mutation; the difference was not significant $(P=0.217)$, possibly because our sample size of cases who underwent octreotide test $(n=20)$ was too small for statistical evaluation. 
Table 3 Summary of clinico-pathological data.

\begin{tabular}{|c|c|c|c|c|c|c|}
\hline & \multicolumn{3}{|c|}{ Adenomae type } & \multirow[b]{2}{*}{$P$ value } & \multirow{2}{*}{$\begin{array}{c}\text { non-DP } \\
\text { adenomae } \\
(n=111)\end{array}$} & \multirow{2}{*}{$\begin{array}{c}\boldsymbol{P} \text { value } \\
\text { (DP versus } \\
\text { non-DP) }\end{array}$} \\
\hline & DP $(n=30)$ & MP $(n=28)$ & $\mathbf{P P}(n=83)$ & & & \\
\hline Age (years; mean \pm S.D.) & $45.0 \pm 16.1$ & $48.7 \pm 12.9$ & $50.6 \pm 12.5$ & $0.228^{a}$ & $50.1 \pm 12.6$ & $0.098^{\mathrm{b}}$ \\
\hline \multicolumn{7}{|l|}{ Sex } \\
\hline Male & $11(36.7 \%)$ & $13(46.4 \%)$ & $40(48.2 \%)$ & \multirow[t]{2}{*}{$0.550^{\mathrm{c}}$} & $53(47.7 \%)$ & \multirow[t]{2}{*}{$0.273^{\mathrm{d}}$} \\
\hline Female & $19(63.3 \%)$ & $15(53.6 \%)$ & $43(51.8 \%)$ & & $58(52.3 \%)$ & \\
\hline Basal GH level (ng/ml; mean \pm s.D.) & $115.7 \pm 326.9$ & $51.5 \pm 65.8$ & $46.2 \pm 130.5$ & $0.249^{\mathrm{a}}$ & $47.5 \pm 117.3$ & $0.184^{\mathrm{b}}$ \\
\hline Size $(\mathrm{mm} ;$ mean \pm s.D. $)$ & $23.5 \pm 11.5$ & $16.8 \pm 8.2$ & $17.6 \pm 8.9$ & $0.020^{\mathrm{a}}$ & $17.4 \pm 8.7$ & $0.006^{\mathrm{b}}$ \\
\hline Microadenomae & $2(6.7 \%)$ & $3(14.9 \%)$ & $16(19.3 \%)$ & $0.197^{\mathrm{C}}$ & $19(17.1 \%)$ & $0.124^{d}$ \\
\hline Macroadenomae & $28(93.3 \%)$ & $25(89.3 \%)$ & $67(80.7 \%)$ & & $92(82.9 \%)$ & \\
\hline Volume $\left(\mathrm{cm}^{3} ;\right.$ mean \pm S.D. $)$ & $11.7 \pm 18.4$ & $4.6 \pm 10.5$ & $5.8 \pm 11.04$ & $0.021^{\mathrm{a}}$ & $5.3 \pm 10.9$ & $0.006^{\mathrm{b}}$ \\
\hline $\begin{array}{l}\text { GH-producing index }\left(\mathrm{ng} / \mathrm{ml} \text { per } \mathrm{cm}^{3}\right. \\
\text { mean } \pm \text { s.D. }\end{array}$ & $17.3 \pm 22.2$ & $23.8 \pm 39.4$ & $23.1 \pm 39.2$ & $0.255^{\mathrm{a}}$ & $23.2 \pm 39.1$ & $0.145^{\mathrm{b}}$ \\
\hline \multicolumn{7}{|l|}{ Invasion in macroadenomae $e^{\mathrm{e}}$} \\
\hline Invasive & $10(35.7 \%)$ & $4(16 \%)$ & $24(35.8 \%)$ & \multirow[t]{2}{*}{$0.167^{\mathrm{c}}$} & $28(30.4 \%)$ & \multirow[t]{2}{*}{$0.599^{d}$} \\
\hline Non-invasive & $18(64.3 \%)$ & $21(84 \%)$ & $43(64.2 \%)$ & & $64(69.6 \%)$ & \\
\hline \multicolumn{7}{|l|}{ TRH test } \\
\hline Normal response & $13(48.1 \%)$ & $1(4.2 \%)$ & $18(23.4 \%)$ & \multirow[t]{2}{*}{$0.001^{c}$} & $19(18.8 \%)$ & \multirow[t]{2}{*}{$0.003^{d}$} \\
\hline Abnormal response & $14(51.9 \%)$ & $23(95.8 \%)$ & $59(76.6 \%)$ & & $82(81.2 \%)$ & \\
\hline \multicolumn{7}{|l|}{ LHRH test } \\
\hline Normal response & $26(96.3 \%)$ & $19(79.2 \%)$ & $62(80.5 \%)$ & \multirow[t]{3}{*}{$0.132^{\mathrm{C}}$} & $81(80.2 \%)$ & \multirow[t]{3}{*}{$0.034^{d}$} \\
\hline Abnormal response & $1(3.7 \%)$ & $5(20.8 \%)$ & $15(19.5 \%)$ & & $20(19.8 \%)$ & \\
\hline \multicolumn{5}{|l|}{ Octreotide test } & & \\
\hline Good response & 0 & $3(50 \%)$ & $9(42.9 \%)$ & \multirow[t]{2}{*}{$0.033^{c}$} & $12(42.9 \%)$ & \multirow[t]{2}{*}{$0.008^{d}$} \\
\hline Poor response & $11(100 \%)$ & $4(50 \%)$ & $12(57.1 \%)$ & & $16(57.1 \%)$ & \\
\hline \multicolumn{7}{|l|}{ Surgical outcome } \\
\hline Cured $^{f}$ & $11(42.3 \%)$ & $12(52.2 \%)$ & $49(62.8 \%)$ & \multirow[t]{2}{*}{$0.167^{c}$} & $61(60.4 \%)$ & \multirow[t]{2}{*}{$0.076^{d}$} \\
\hline Non-cured & $15(57.7 \%)$ & $11(47.8 \%)$ & $29(37.2 \%)$ & & $40(39.6 \%)$ & \\
\hline
\end{tabular}

Non-dot pattern, perinuclear pattern + mixed pattern; GH-producing index, basal GH level per $\mathrm{cm}^{3}$ volume; bold numerals, $P<0.05$.

${ }^{a}$ Kruskal-Wallis test.

bMann-Whitney test.

c Contingency $C$ test.

${ }^{\text {d}}$ Fisher's exact test.

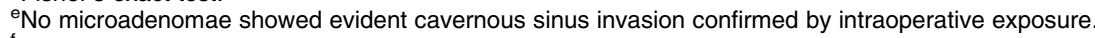

${ }^{f}$ Cured: nadir GH during glucose tolerance test $<1.0 \mathrm{ng} / \mathrm{ml}$ and normalised IGF1 level (based on standard value for normal Japanese population).

\section{Discussion}

The classification of GHomae based on their CK immunostaining patterns results in three subtypes, i.e. DP, PP and MP tumours (7-11). We found some different clinico-pathological features in DP adenomae than in non-DP adenomae.

\section{CK staining patterns and clinico-pathological features}

The age tended to be lower in patients with DP than those with non-DP GHomae $(P=0.98)$. This finding coincides with the report of Mazal et al. (11) and Obari et al. (9). With respect to the tumour size, our findings were similar to the findings reported by Mazal et al. (11) who also observed that DP adenomae were significantly larger than non-DP adenomae. While the difference was not statistically significant $(P=0.086)$, the MIB- 1 index, indicative of the proliferative activity of tumour cells, tended to be higher in our patients with DP adenomae than those with non-DP adenomae. According to Mazal et al. (11), it was significantly higher in DP tumours than in PP tumours, suggesting that the DP subtype may be more highly proliferative. One of our patients manifested an atypical GHoma that regrew rapidly and recurred postoperatively; the MIB-1 index was $\sim 10 \%$, and $23 \%$ of the cell nuclei were positive for p53. Based on CK immunostaining, this tumour was classified as a DP subtype adenoma. In our study, more DP tumours than non-DP tumours expressed p53, although the difference was not statistically significant $(P=0.101)$. Our patients with DP adenomae were younger than those with non-DP tumours, possibly because the former subtype is more highly proliferative and consequently, these tumours tend to be larger. Besides excessive $\mathrm{GH}$ secretion, cranial nerve signs and headache may be clues for a diagnosis of acromegaly, and these non-hormonal manifestations may appear earlier in patients with DP adenomae due to their larger size.

The expression of E-cadherin was significantly lower in DP adenomae than in non-DP adenomae $(P<0.001)$; a finding that coincides with observations reported by others $(8,10)$. The E-cadherin cell adhesion system is involved in cell-cell interactions via coupling to cytoskeleton-associated desmosomal proteins (27). As E-cadherin is critical for the anchoring of CK filaments to the cell surface, the loss of E-cadherin expression on 
Table 4 Summary of immunohistochemistry data. Results are mean \pm s.D.

\begin{tabular}{|c|c|c|c|c|c|c|}
\hline & \multicolumn{3}{|c|}{ Adenomae type } & \multirow[b]{2}{*}{$P$ value $^{\mathrm{a}}$} & \multirow{2}{*}{$\begin{array}{c}\text { non-DP } \\
\text { adenomae } \\
(n=111)\end{array}$} & \multirow{2}{*}{$\begin{array}{c}\boldsymbol{P} \text { value } \\
\text { (DP versus } \\
\text { non-DP) }\end{array}$} \\
\hline & $\mathbf{D P}(n=30)$ & MP $(n=28)$ & $\mathbf{P P}(n=83)$ & & & \\
\hline GH (\%) & $>90 \%$ & $>90 \%$ & $>90 \%$ & $N / A$ & $>90 \%$ & $N / A$ \\
\hline PRL (\%) & $6.6 \pm 11.2$ & $18.0 \pm 21.4$ & $11.4 \pm 18.0$ & 0.113 & $13.1 \pm 19.1$ & 0.226 \\
\hline$\beta \mathrm{TSH}(\%)$ & $0.19 \pm 1.04$ & $0.18 \pm 0.97$ & $1.04 \pm 4.49$ & 0.374 & $0.82 \pm 3.92$ & 0.371 \\
\hline MIB-1 index (\%) & $0.72 \pm 1.6$ & $0.29 \pm 0.63$ & $0.17 \pm 0.25$ & 0.162 & $0.20 \pm 0.39$ & 0.086 \\
\hline MVD & $32.8 \pm 23.4$ & $27 \pm 24.3$ & $35 \pm 23.7$ & 0.365 & $33.4 \pm 24.0$ & 0.927 \\
\hline E-cadherin (\%) & $9.9 \pm 25.1$ & $54.3 \pm 26.3$ & $70.2 \pm 35.3$ & $<0.001$ & $66.5 \pm 33.9$ & $<0.001$ \\
\hline p53 (\%) & $1.21 \pm 4.25$ & $0.48 \pm 0.79$ & $0.28 \pm 0.75$ & 0.101 & $0.33 \pm 0.76$ & 0.363 \\
\hline
\end{tabular}

MIB-1 index, percentage of positive nucleus for KI- 67 staining of more than 500 cells; MVD, microvascular density; N/A, not applicable. Bold numerals, $P<0.05$. ${ }^{a}$ Kruskal-Wallis test.

${ }^{\mathrm{b}}$ Mann-Whitney test.

the cell membrane results in CK collapse (28) and may facilitate the formation of a fibrous body that stains with CAM-5.2 in GHomae. As the disruption of cell-cell contact is a key step in tumour progression, the loss of E-cadherin expression has been observed in various carcinomas (29). The disruption of cell-cell contact due to impaired E-cadherin expression may be a factor in the growth of DP adenomae. Other factors influencing tumour growth, such as apoptotic process, cell-cell junction and intercellular communication, should be further investigated to understand the linking mechanisms between CK expression and tumour growth.

DP adenomae did not have the tendency to be more invasive than the other types; a finding that is inconsistent with the reports by Mazal et al. (11) and Obari et al. (9), where both groups determined invasion by Knosp grading (26). However, we evaluated the invasion into cavernous sinus based on intraoperative findings under microscopic and/or endoscopic observations in addition to preoperative MRI findings. The discrepancy may have resulted from the difference in defining 'invasion'.

With respect to hormone production, we found no significant difference in immunoreactivity to GH, TSH and PRL between DP and non-DP adenomae. Although statistically insignificant, the GH-producing index was lower in DP adenomae than in non-DP adenomae in our study. This could have been due to the larger tumour size and smaller number and size of secretion granules (electron microscopic features) of DP adenomae than those of PP adenomae (1). Accordingly, Nishioka et al. (8) have also reported that an increased percentage of fibrous body is associated with lower basal $\mathrm{GH}$ levels per unit volume of tumour tissue and decreased immunoreactivities to GH and PRL.

Table 5 A summary of implication of gsp gene mutation on clinico-pathological features.

\begin{tabular}{|c|c|c|c|}
\hline Clinico-pathological data & Mutated type & Wild-type & $P$ value \\
\hline \multicolumn{4}{|l|}{ Cytokeratin (CK) pattern ${ }^{\mathrm{a}}$} \\
\hline Dot pattern $(n=13)$ & $5(38.5 \%)$ & $8(61.5 \%)$ & $0.083^{\mathrm{b}}$ \\
\hline Non-dot pattern $(n=30)$ & $20(66.7 \%)$ & $10(33.3 \%)$ & \\
\hline Age (mean \pm s.D.) & $50.2 \pm 13.9$ & $44.7 \pm 13.7$ & $0.218^{\mathrm{C}}$ \\
\hline \multicolumn{4}{|l|}{ Sex $-1-1$} \\
\hline Male & $13(52 \%)$ & $5(27.8 \%)$ & $0.101^{\mathrm{b}}$ \\
\hline Female & $12(48 \%)$ & $13(72.2 \%)$ & \\
\hline Basal GH levels (ng/ml; mean \pm s.D.) & $44.1 \pm 41.1$ & $43.1 \pm 54.8$ & $0.313^{\mathrm{c}}$ \\
\hline Size (mm; Mean+s.D.) & $16.3+4.8$ & $24.2+9.4$ & $0.006^{\mathrm{C}}$ \\
\hline Volume $\left(\mathrm{cm}^{3} ;\right.$ mean \pm S.D. $)$ & $2.8 \pm 2.3$ & $10.1 \pm 8.9$ & $0.007^{\mathrm{C}}$ \\
\hline $\mathrm{GH}$-producing index $\left(\mathrm{ng} / \mathrm{ml}\right.$ per $\mathrm{cm}^{3} ;$ mean \pm s.D. $)$ & $26.5 \pm 29.9$ & $12.2 \pm 17.3$ & $0.007^{c}$ \\
\hline \multicolumn{4}{|l|}{ TRH test } \\
\hline Normal response & $0(0 \%)$ & $9(50 \%)$ & $<0.001^{b}$ \\
\hline Abnormal response & $25(100 \%)$ & $9(50 \%)$ & \\
\hline \multicolumn{4}{|l|}{ LHRH test } \\
\hline Normal response & $23(92.0 \%)$ & $13(72.2 \%)$ & $0.095^{\mathrm{b}}$ \\
\hline Abnormal response & $2(8 \%)$ & $5(27.8 \%)$ & \\
\hline \multicolumn{4}{|l|}{ Octreotide test } \\
\hline Good response & $4(44.4 \%)$ & 2 (18.2\%) & $0.217^{b}$ \\
\hline Poor response & $5(55.6 \%)$ & $9(81.8 \%)$ & \\
\hline MIB-1 index (\%; mean \pm s.D.) & $0.22 \pm 0.31$ & $0.45 \pm 1.11$ & $0.697^{\mathrm{C}}$ \\
\hline
\end{tabular}

aPercentage with a cytokeratin (CK) pattern. Bold numerals, $P<0.05$.

${ }^{\mathrm{b}}$ Fisher's exact test.

cMann-Whitney test. 
We routinely perform TRH and LHRH tests on patients with GHoma to assess the preoperative and postoperative secretory dynamics of the pituitary hormones: TSH, PRL, LH and FSH. Abnormal GH responses to these tests provide additional evidence for acromegaly, and persistent abnormal responses to TRH challenge in cured acromegalics are thought to be predictive of recurrence (30). In this study, the incidence of abnormal response to preoperative TRH or LHRH challenge test was significantly $(P<0.05)$ lower in DP adenomae than in non-DP adenomae. Ectopic TRH receptors in GHomae cells play an important role in the abnormal GH response to TRH (31). Physiologically, TRH receptors act via the inositol 1,4,5-triphosphate pathway to release TSH and PRL (32, 33). However, ectopically expressed TRH receptors cross-couple with cAMP and regulate $\mathrm{GH}$ secretion by somatotroph cells (34), and the abnormal $\mathrm{GH}$ response is more frequently observed in adenomae with gsp mutation than those without the mutation (35) as is in our series. As gsp mutation was more frequently encountered in non-DP adenomae in this study, it is thus rational to expect $\mathrm{TRH}$ receptor prevailed more frequently in DG GHomae than in SG ones (31). Ectopic expression of TRH receptors may couple with tumourigenesis of GHomae (triggered by $g s p$ mutation) and amplified cAMP signalling $(36,37)$.

The response rate to the prolonged administration of octreotide was reported to be significantly higher in patients with DG adenomae than those with SG adenomae $(38,39)$. In our series, the response to octreotide was higher in patients with non-DP adenomae than those with DP adenomae. In fact, all patients manifesting a good octreotide response had abnormal responses to TRH challenge, while this was true for $55.6 \%$ of patients with a poor response to octreotide (data not shown in table). The difference in the frequency of positive response to octreotide test may be partially due to the different $g s p$ mutation prevalence between DP and non-DP adenomae. Somatostatin receptor subtype-2 (SSTR2), to which octreotide preferentially binds, is overexpressed by the constitutive activation of adenylyl cyclase in GHomae with gsp mutation (40). Nakashima et al. (41) have reported that adenomae with gsp mutation are more likely to display plasma membrane-dominant staining of SSTR2A. Elucidating the differences in expression and distribution of somatostatin receptors and their intracellular signalling between DP and non-DP GHomae cells are themes that need further investigation.

Postoperative cure rate was better in non-DP adenomae (60.4\%) than in DP adenomae $(42.3 \%)$ in our series $(P=0.076)$, which would be a reflection of the smaller volume in non-DP adenomae. Lack of the statistical significance may be due to relatively lower $\mathrm{GH}$ productivity of DP adenomae. Because of the lower GH productivity, patients with limited residual adenomae tissue with DP might be judged as 'cured' by the current consensus criteria of cure (42).

\section{gsp mutations and CK staining pattern}

Although the number of adenomae available for analysis of the relationship between $g s p$ mutations and the CK staining pattern was limited $(n=43)$, we found that $38.5 \%$ of the DP tumours manifested the mutation. This finding differs from the observations reported by Asa et al. (23), suggesting that in GHomae the CK architecture may not be related directly with $g s p$-induced tumourigenesis.

The rate of the $g s p$ mutation in our series $(58.1 \%)$ is comparable to the rate reported in Caucasian patients (19-21) and in a recent series of 100 Japanese patients (53.0\%) (18). In studies reported in 1993, the incidence of $g s p$ mutations in Japanese acromegalics was low as 9.3 and $4.4 \%(43,44)$; however, re-evaluation performed 10 years later by the same authors indicated that the corrected incidence was 53.1\% (45).

Findings on the relationship between the presence of gsp mutations and tumour size have been discordant (19-21, 46). In our study, adenomae with gsp mutations were significantly smaller $(P<0.01)$ than tumours without $g s p$ mutations. We posit that the smaller size of our non-DP adenomae may be partly attributable to the higher incidence of $g s p$ mutations in that adenoma subtype.

\section{Conclusion}

DP somatotropinomae exhibit characteristic features. Compared with the non-DP subtypes, the DP tumours were larger; patients with DP tumours had a lower incidence of abnormal responses to TRH and LHRH challenge and a poorer response to octreotide test. Lastly, the E-cadherin expression level was lower in DP adenomae than in non-DP adenomae, a factor that may explain their larger size. Both DP and non-DP tumours manifested $g s p$ mutations. Additional investigations are necessary to elucidate the molecular background of the observed differences in the CK staining patterns and to understand their relationship with tumourigenesis.

\section{Declaration of interest}

We declare that no authors have any conflict of interest with respect to financial relationships, stock options, board memberships, consulting agreements, advisory council memberships, honoraria, ownership interests and royalties, and that none has served as a spokesperson or expert witness, or given testimony. There are no conflicts that could be perceived as prejudicing the impartiality of the research reported.

\section{Funding}

This study was financed by a Health and Labor Sciences Research Grant on 'Research on Intractable Diseases in Japan: HypothalamoPituitary Dysfunction' awarded to K Arita and by a Grant-in-aid (no: 20591716) from the Ministry Education, Culture, Sports, Science, and Technology of Japan. 


\section{References}

1 Asa SL. Tumors of the pituitary gland. In Atlas of Tumor Pathology, Series 3, Fascicle 22, pp 47-131. Washington: Armed Forces Institute of Pathology, 1998.

2 Osamura RY, Tamara S, Curtain R, Sino N, Matsuno A \& Teramoto A. Contributions of immunohistochemistry and hybridization to the functional analysis of pituitary adenomas. Journal of Histochemistry and Cytochemistry 200048 445-458.

3 Thapar K \& Laws ER. Pituitary tumors: functioning and nonfunctioning. In Youmans Neurological Surgery, 5th edn, vol 1, pp 1169-1207. Eds HR Winn, R Sawaya \& H Brem. Philadelphia: Saunders, 2004.

4 Horvath E \& Kovacs K. The adenohypophysis. In Functional Endocrine Pathology, vol 1, pp 242-281. Eds K Kovacs \& SL Asa. Boston, PA: Blackwell, 1991.

5 Kontogeorgos G, Watson Jr RE, Lindell EP, Barken AL, Farrell WE \& Lloyd RV. Growth hormone producing adenoma. In Pathology and Genetics of Tumors of Endocrine Organs (World Health Organization Classification of Tumours series), pp 14-19. Eds RS DeLellis, RV Lloyd, PU Heitz \& C Eng. Lyon, PA: IARC Press, 2004.

6 Horvath E \& Kovacs K. Morphogenesis and significance of fibrous bodies in human pituitary adenomas. Virchows Archiv. B: Cell Pathology 197827 69-78. (doi:10.1007/BF02888984)

7 Yamada S, Aiba T, Sano T, Kovacs K, Shishiba Y, Kawano S \& Takada K. Growth hormone-producing pituitary adenomas: correlations between clinical characteristics and morphology. Neurosurgery 199333 20-27. (doi:10.1227/00006123-19930 7000-00003)

8 Nishioka H, Haraoka J \& Akada K. Fibrous bodies are associated with lower $\mathrm{GH}$ production and decreased expression of E-cadherin in GH-producing pituitary adenoma. Clinical Endocrinology 2003 59 768-772. (doi:10.1046/j.1365-2265.2003.01921.x)

9 Obari A, Sano T, Oyama K, Kudo E, Oian ZR, Yoneda A, Nasim R, Rahman MM \& Yamada S. Clinicopathological features of growth hormone-producing pituitary adenomas: difference among various types defined by cytokeratin distribution pattern including a transitional form. Endocrine Pathology 2008 19 82-91. (doi:10.1007/s12022-008-9029-z)

10 Sano T, Yamada S, Hirose T \& Hirazawa K. Cytokeratin distribution and functional properties of growth hormoneproducing pituitary adenomas. Endocrine Pathology 19945 107-113. (doi:10.1007/BF02921378)

11 Mazal PR, Czech T, Sedivy R, Aichholzer M, Wenschitz J, Klupp N \& Budka H. Prognostic relevance of intracytoplasmic cytokeratin pattern, hormonal expression profile and cell proliferation in pituitary adenomas of acromegalic patients. Clinical Neuropathology 200120 163-173.

12 Neumann PE, Goldman JE, Horoupian DS \& Hess MA. Fibrous bodies in growth hormone-secreting adenomas contain cytokeratin filaments. Archives of Pathology \& Laboratory Medicine 1985 109 505-508.

13 Kasper M, Stosiek P, Van Muijen GNP \& Moll R. Cell type heterogeneity of intermediate filament expression in epithelia of the human pituitary gland. Histochemistry 198993 93-103. (doi:10.1007/BF00266853)

14 Toivola DM, Tao GZ, Habtezion A, Liao J \& Omary MB. Cellular integrity plus organelle-related and protein-targeting functions on intermediate filaments. Trends in Cell Biology 200515 608-617. (doi:10.1016/j.tcb.2005.09.004)

15 Chu PG \& Weiss LM. Keratin expression in human tissues and neoplasms. Histopathology 200240 403-439. (doi:10.1046/ j.1365-2559.2002.01387.x)

16 Vallar L, Spada A \& Giannattasio G. Altered $\mathrm{G}_{\mathrm{s}}$ and adenylate cyclase activity in human GH-secreting pituitary adenomas. Nature 1987330 566-568. (doi:10.1038/330566a0)

17 Landis CA, Masters SB, Spada A. Pace AM, Bourne HR \& Vallar L. GTPase inhibiting mutations activate the $\alpha$ chain of $G_{s}$ and stimulate adenylyl cyclase in human pituitary tumours. Nature 1989340 692-696. (doi:10.1038/340692a0)
18 Yasufuku-Takano J, Takano K, Morita K, Takakura K, Teramoto A $\&$ Fujita T. Does the prevalence of $g s p$ mutations in GH-secreting pituitary adenomas differ geographically or racially? Prevalence of $g s p$ mutations in Japanese patients revisited Clinical Endocrinology 200664 91-96. (doi:10.1111/j.1365-2265.2005. 02423.x)

19 Spada A, Arosio M, Bochicchio D, Bazzoni N, Vallar L, Bassetti M \& Faglia G. Clinical, biochemical, and morphological correlates in patients bearing growth hormone-secreting pituitary tumours with or without constitutively active adenylyl cyclase. Journal of Clinical Endocrinology and Metabolism $1990 \quad 71$ 1421-1426. (doi:10.1210/jcem-71-6-1421)

20 Landis CA, Harsh G, Lyons J, Davis RL, McCormick F \& Bourne HR. Clinical characteristics of acromegalic patients whose pituitary tumors contain mutant $\mathrm{G}_{\mathrm{s}}$ protein. Journal of Clinical Endocrinology and Metabolism 199071 1416-1420. (doi:10.1210/jcem-71-61416)

21 Harris PE, Alexander JM, Bikkal HA, Hsu DW, Hedley-Whyte ET, Klibanski A \& Jameson JL. Glycoprotein hormone $\alpha$-subunit production in somatotroph adenomas with and without $G_{s}$ alpha mutations. Journal of Clinical Endocrinology and Metabolism 1992 75 918-923. (doi:10.1210/jc.75.3.918)

22 Buchfelder M, Fahlbusch R, Merz T, Symowski H \& Adams EF. Clinical correlates in acromegalic patients with pituitary tumors expressing gsp oncogenes. Pituitary 19991 181-185. (doi:10. 1023/A:1009905131334)

23 Asa SL, Digiovanni R, Jiang J. Ward ML, Loesch K, Yamada S, Sano T, Yoshimoto K, Frank SJ \& Ezzat S. A growth hormone receptor mutation impairs growth hormone auto feedback signaling in pituitary tumors. Cancer Research 200767 7505-7511. (doi:10.1158/0008-5472.CAN-07-0219)

24 Giustina A, Barkan A, Casanueva FF, Cavagnini F, Frohman L, Ho K, Veldhuis J, Wass J, Von Werder K \& Melmed S. Criteria for cure of acromegaly: a consensus statement. Journal of Clinical Endocrinology and Metabolism 200085 526-529. (doi:10.1210/ jc.85.2.526)

25 Lundin P \& Pedersen F. Volume of pituitary macroadenomas: assessment by MRI. Journal of Computer Assisted Tomography 1992 16 519-528. (doi:10.1097/00004728-199207000-00004)

26 Knosp E, Steiner E, Kitz K \& Matula C. Pituitary adenomas with invasion of the cavernous sinus space: a magnetic resonance imaging classification compared with surgical findings. Neurosurgery $1993 \quad 33$ 610-617. (doi:10.1227/00006123. 199310000-00008)

27 Lehr HA, Folpe A, Yaziji H, Kommoss F \& Gown AM. Cytokeratin 8 immunostaining pattern and E-cadherin expression distinguish lobular from ductal breast carcinoma. American Journal of Clinical Pathology 2000114 190-196. (doi:10.1309/CPUX-KWEH7B26-YE19)

28 Amagai M, Fujimori T, Masunaga T, Shimizu H, Nishikawa T, Shimizu N, Takeichi M \& Hashimoto T. Delayed assembly of desmosomes in keratinocytes with disrupted classic-cadherinmediated cell adhesion by dominant negative mutant. Journal of Investigative Dermatology 1995104 27-32. (doi:10.1111/15231747.ep12613462)

29 Takeichi M. Cadherin in cancer: implication for invasion and metastasis. Current Opinion in Cell Biology 19935 806-811. (doi:10.1016/0955-0674(93)90029-P)

30 Biermasz NR, Smit JW, van Dulken H \& Roelfsema F. Postoperative persistent thyrotrophin releasing hormone-induced growth hormone release predicts recurrence in patients with acromegaly. Clinical Endocrinology 200256 313-319. (doi:10.1046/j.13652265.2002.01465.x)

31 Igarashi-Migitaka J, Yamada S, Hara M, Sano T, Ozawa Y, OhtaniKaneko R \& Hirata K. Gene expression study of thyrotropin releasing hormone (TRH) receptor using RT-PCR: relationship to clinical and immunohistochemical phenotypes in a series of human pituitary adenomas. Endocrine Journal 200350 459-467. (doi:10.1507/endocrj.50.459) 
32 Hinkle PM \& Tashjian AH Jr. Thyrotropin-releasing hormone regulates the number of its own receptors in the GH3 strain of pituitary cells in culture. Biochemistry 197514 3845-3851. (doi:10.1021/bi00688a017)

33 Winicov I \& Gershengorn MC. Receptor density determines secretory response patterns mediate by inositol lipid-derived second messengers. Comparison of thyrotropin-releasing hormone and carbamylcholine actions in thyroid-stimulating hormonesecreting mouse pituitary tumour cells. Journal of Biological Chemistry $1989 \mathbf{2 6 4} 9438-9443$.

34 Tomić M, Zivadinovic D, Van Goor F, Yuan D, Koshimizu T \& Stojilkovic SS. Expression of $\mathrm{Ca}(2+)$-mobilizing endothelin (A) receptors and their role in the control of $\mathrm{Ca}(2+)$ influx and growth hormone secretion in pituitary somatotrophs. Journal of Neuroscience 199919 7721-7731.

35 Yang I, Park S, Ryu M, Woo J, Kim S, Kim J, Kim Y \& Choi Y. Characteristics of $g s p$-positive growth hormone-secreting pituitary tumors in Korean acromegalic patients. European Journal of Endocrinology 1996134 720-726. (doi:10.1530/eje.0.1340720)

36 Gershengorn MC \& Thaw CN. Regulation of thyrotropin-releasing hormone receptors is cell type specific: comparison of endogenous pituitary receptors and receptors transfected into non-pituitary cells. Endocrinology 1991128 1204-1206. (doi:10.1210/endo128-2-1204)

37 Akintoye SO, Chebli C, Booher S, Feuillan P, Kushner H, Leroith D, Cherman N, Bianco P, Wientroub S, Robey PG \& Collins MT. Characterization of $g s p$-mediated growth hormone excess in the context of McCune-Albright syndrome. Journal of Clinical Endocrinology and Metabolism 200287 5104-5112. (doi:10. 1210/jc.2001-012022)

38 Bhayana S, Booth GL, Asa SL, Kovacs K \& Ezzat S. The implication of somatotroph adenoma phenotype to somatostatin analog responsiveness in acromegaly. Journal of Clinical Endocrinology and Metabolism 200590 6290-6295. (doi:10.1210/jc.20050998)

39 Ezzat S, Kontogeorgos G, Redelmeier DA, Horvath E, Harris AG \& Kovacs K. In vivo responsiveness of morphological variants of growth hormone-producing pituitary adenomas to octreotide. European Journal of Endocrinology 1995133 686-690. (doi:10. 1530/eje.0.1330686)
40 Patel YC, Greenwood M, Kent G, Panetta R \& Srikant CB. Multiple gene transcripts of the somatostatin receptor SSTR2: tissue selective distribution and cAMP regulation. Biochemical and Biophysical Research Communications $1993192 \quad 288-294$. (doi:10.1006/bbrc.1993.1412)

41 Nakashima M, Takano K \& Matsuno A. Analyses of factors influencing the acute effect of octreotide in growth hormonesecreting adenomas. Endocrine Journal 200956 295-304. (doi:10. 1507/endocrj.K08E-305)

42 Nishioka H \& Haraoka J. Biochemical cure of acromegaly after transsphenoidal surgery despite residual tumor on magnetic resonance imaging - case report. Neurologia Medico-Chirurgica 200848 311-313. (doi:10.2176/nmc.48.311)

43 Hosoi E, Yokogoshi Y, Hosoi E, Horie H, Sano T, Yamada S \& Saito S. Analysis of the $\mathrm{G}_{\mathrm{s}}$ alpha gene in growth hormone-secreting pituitary adenomas by the polymerase chain reaction-direct sequencing method using paraffin-embedded tissues. Acta Endocrinologica 1993 129 301-306. (doi:10.1530/acta.0.1290301)

44 Yoshimoto K, Iwahana H, Fukuda A, Sano T \& Itakura M. Rare mutations of the $\mathrm{G}_{\mathrm{s}}$ alpha subunit gene in human endocrine tumors. Mutation detection by polymerase chain reactionprimer-introduced restriction analysis. Cancer $1993 \quad \mathbf{7 2}$ 1386-1393. (doi:10.1002/1097-0142(19930815)72:4<1386:: AID-CNCR2820720439>3.0.CO;2-J)

45 Yamasaki H, Mizusawa N, Nagahiro S, Yamada S, Sano T, Itakura M \& Yoshimoto K. GH-secreting pituitary adenomas infrequently contain inactivating mutations of PRKAR1A and LOH of 17q23-24. Clinical Endocrinology $2003 \mathbf{5 8}$ 464-470. (doi:10.1046/j.1365-2265.2003.01740.x)

46 Adams EF, Brockmeier S, Friedmann E, Roth M, Buchfelder M \& Fahlbusch R. Clinical and biochemical characteristics of acromegalic patients harboring $g s p$-positive and $g s p$-negative pituitary tumors. Neurosurgery 199333 198-203. (doi:10.1227/ 00006123-199308000-00003)

Received 26 July 2010

Accepted 5 August 2010 